\title{
The Endolysosomal System and Proteostasis: From Development to Degeneration
}

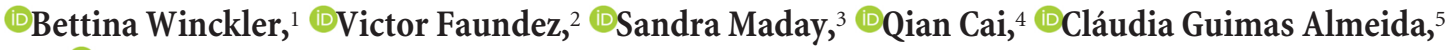 \\ and ${ }^{\circ}$ Huaye Zhang ${ }^{6}$ \\ ${ }^{1}$ Department of Cell Biology, University of Virginia Health System, Charlottesville, Virginia 22908, ${ }^{2}$ Department of Cell Biology, Emory University, Atlanta, \\ Georgia 30322, ${ }^{3}$ Department of Neuroscience, Perelman School of Medicine, University of Pennsylvania, Philadelphia, Pennsylvania 19104, ${ }^{4}$ Department of \\ Cell Biology and Neuroscience, Rutgers, State University of New Jersey, Piscataway, New Jersey $08854,{ }^{5}$ Chronic Diseases Research Center, NOVA Medical \\ School, Universidade NOVA de Lisboa, Lisbon, Portugal 1169-056, and 'Department of Neuroscience and Cell Biology, Rutgers Robert Wood Johnson \\ Medical School, Piscataway, New Jersey 08854
}

How do neurons adapt their endolysosomal system to address the particular challenge of membrane transport across their elaborate cellular landscape and to maintain proteostasis for the lifetime of the organism? Here we review recent findings that address this central question. We discuss the cellular and molecular mechanisms of endolysosomal trafficking and the autophagy pathway in neurons, as well as their role in neuronal development and degeneration. These studies highlight the importance of understanding the basic cell biology of endolysosomal trafficking and autophagy and their roles in the maintenance of proteostasis within the context of neurons, which will be critical for developing effective therapies for various neurodevelopmental and neurodegenerative disorders.

Key words: endosomes; membrane trafficking; polarity; neurons; autophagy; lysosome

\section{Introduction}

Neurons are extremely large cells with a long axon and multiple dendrites extending over centimeters or more. This large size creates significant challenges for regulating transport of membrane components, both from the biosynthetic pathway to deliver membrane proteins to their correct locations, as well as for removing membrane proteins from the surface and transporting them to new sites or to degrade them. In addition, neurons are extremely active, firing action potentials at rates up to $\sim 50-100$ impulses per second (Harris and Attwell, 2012), and they must sustain this activity for nearly a century! Consequently, the neuronal proteome is vulnerable to damage. The proteome susceptibility to damage is compounded by the longer half-life of neuronal proteins, in particular the synaptic proteome, compared with other tissues and cellular compartments (Price et al., 2010; Heo et al., 2018). To support their long-term viability and functionality, neurons require robust intracellular trafficking machinery and quality control mechanisms (Cajigas et al., 2010;

\footnotetext{
Received Aug. 1, 2018; revised Sept. 17, 2018; accepted Sept. 20, 2018.

This work was supported by National Institutes of Health Grants NS081674 and NS083378 to B.W., AG060285 to V.F., NS089737 and NS102780 to Q.C., and NS089578 to H.Z. S.M. was supported by National Institutes of Health Grant NS082619, the McCabe Fund Fellow Award, the University of Pennsylvania Alzheimer's Disease Core Center, the Intellectual and Developmental Disabilities Research Center at the Children's Hospital of Philadelphia and the University of Pennsylvania, and the Philadelphia Foundation. C.G.A. was supported by Maratona da Saude Award H2020/JPND (JPCOFUND/0004/2015-NAB3) and iNOVA4Health (UID/Multi/04462/2013, Fundação para a Ciência e Tecnologia/Ministério da Educação e Ciência/PT2020).

The authors declare no competing financial interests.

Correspondence should be addressed to Dr. Huaye Zhang, Department of Neuroscience and Cell Biology, Rutgers Robert Wood Johnson Medical School, 675 Hoes Lane West, Piscataway, NJ 08854. E-mail: huaye.zhang@rutgers.edu.

DOI:10.1523/JNEUROSCI.1665-18.2018

Copyright $\odot 2018$ the authors $\quad 0270-6474 / 18 / 389364-11 \$ 15.00 / 0$
}

Yap and Winckler, 2015; Y. C. Wang et al., 2017), which need to be adapted specifically to accommodate their morphological complexity and longevity.

The endolysosomal system is comprised of a series of membranous organelles specialized for regulating both intracellular trafficking and proteostasis. While decades of research in nonneuronal cells have revealed important regulatory mechanisms for endolysosomal trafficking, recent studies have begun to unveil remarkably complex and spatially compartmentalized mechanisms regulating trafficking and proteostasis in neurons (Morgan et al., 2013; Terenzio et al., 2017; Jin et al., 2018a; Kiral et al., 2018). In the following sections, we will review recent advances in understanding such mechanisms, and their role in neuronal development and degeneration. In addition, we will discuss the regulation of neuronal proteostasis by the autophagy pathway, which intersects with the endolysosomal system to facilitate the elimination of damaged membrane and cytosolic proteins, protein aggregates, and membranous organelles. This review accompanies a minisymposium at the 2018 Society for Neuroscience Annual Meeting with the same title.

\section{The endolysosomal system in neuronal development and homeostasis}

The endolysosomal system has been well studied in nonneuronal cells and broadly classified into several subclasses, including the EE (early endosome), RE (recycling endosome), LE (late endosome), and lys (lysosome). The EE is the major sorting station for endocytosed receptors. Recycling cargos can return to the surface from the EE or from the RE. Degradative cargos fail to enter recycling pathways in the $\mathrm{EE}$ and are progressively sorted into intraluminal vesicles starting in the EE. The EE matures to a 


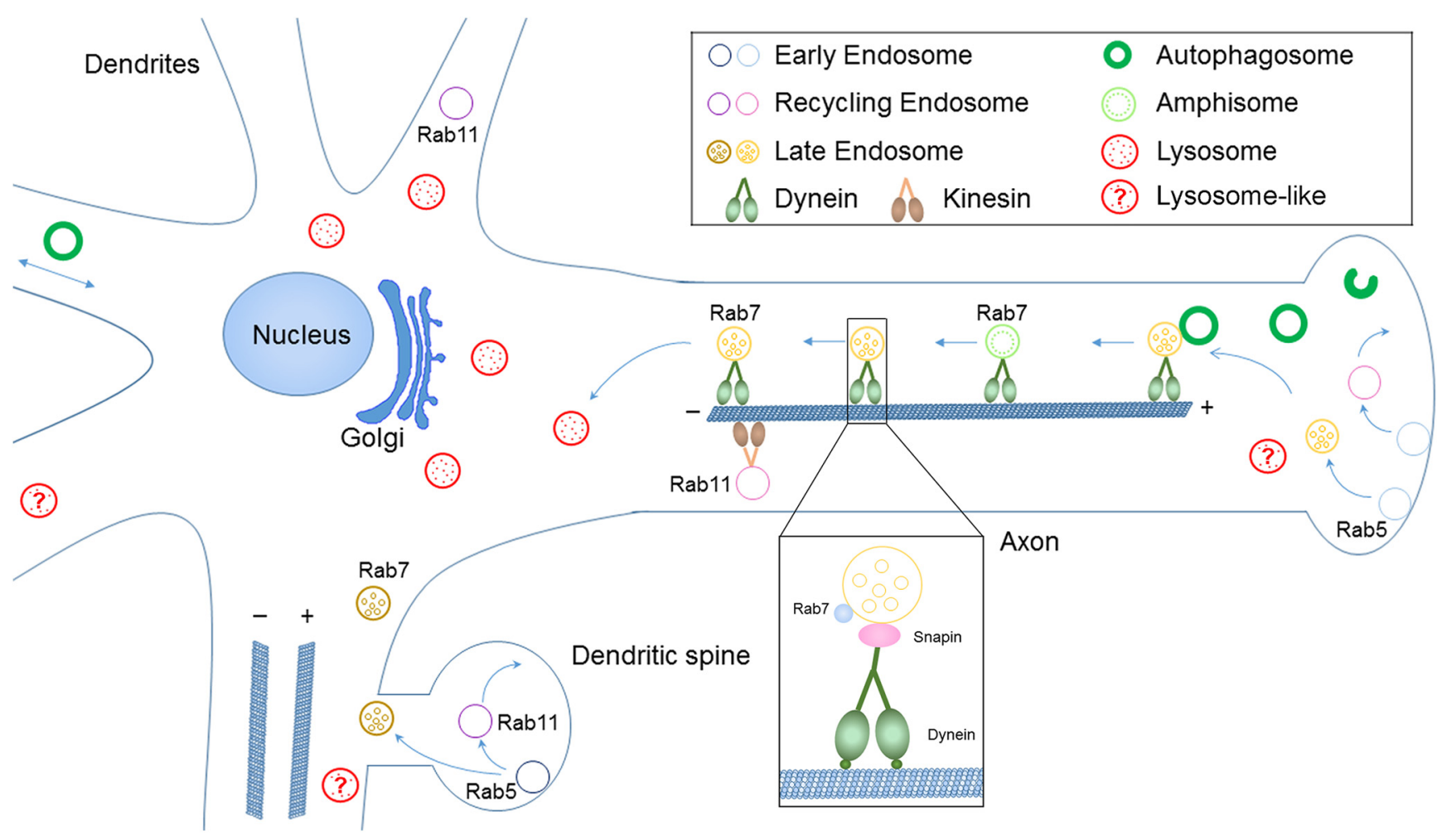

Figure 1. Schematic of endolysosomal trafficking and autophagy in neurons. Distinct endosomal subclasses are associated with particular sets of Rab GTPases. Early endosomes are Rab5-positive, late endosomes are Rab7-positive, and recycling endosomes are Rab11-positive. Endosomal trafficking is differentially regulated in dendrites versus axons of neurons. Mature lysosomes with high degradative capacity are located primarily in the soma or proximal neurites. Immature lysosome-like organelles are found in distal dendrites and axons. Axonal autophagosomes initiate largely in distal regions of the axon and gain retrograde motility through fusion with late endosomes to form amphisomes and coupling with dynein motors. In contrast, dendritic autophagosomes undergo bidirectional motility or oscillate within a confined region along the dendritic shaft.

LE by the timed exchange of specific effectors, proteins that associate with the cytosolic leaflet of the endosome membrane, such as Rab7. LEs contain many intraluminal vesicles and are often categorized by EM as "multivesicular bodies." LEs undergo homotypic fusions with each other as well as fuse with lysosomes for cargo degradation; and in some cases, they fuse with the plasma membrane. From work done primarily in yeast and nonpolarized cells over many years, an impressive regulatory network of proteins is now known to participate in the sorting decision toward degradation. These include the Rab family of small GTPases. Distinct endosomal subclasses are associated with particular sets of Rabs, such as Rab5 for the EE and Rab7 for the LE. Indeed, one of the critical events for conversion of EEs to LEs is that Rab5 is replaced by Rab7. This allows the recruitment of a new set of effectors to the endosomal membrane, which will change the fate of the endosome (Naslavsky and Caplan, 2018).

Compared with endocytic organelles in fibroblasts and other nonpolarized cells, neuronal endolysosomes show a high level of spatial compartmentalization (Fig. 1). During brain development, neurons become highly polarized through extending dendrites and axons, and establishing synaptic connections with distant targets. This raises the intriguing question as to how neurons regulate the transport and degradation of proteins across these subdomains and microcompartments. Studies from different laboratories now support the idea that mature lysosomes with high degradative capacity are located primarily in the soma or proximal neurites (Cai et al., 2010; Lee et al., 2011; Gowrishankar et al., 2015; Maday and Holzbaur, 2016; Tammineni et al., 2017b; Cheng et al., 2018; Yap et al., 2018). Remarkably, there is a strik- ing spatial gradient of endosomal compartments in dendrites, with late endosomes (Rab7-positive/LAMP1-negative/cathepsinBnegative) found throughout dendrites, including distal portions, whereas degradative lysosomes (LAMP1-positive/cathepsinBpositive) are found in the soma and in the proximal portions of dendrites, but not distally. Surprisingly, the majority of dendritic Rab7-positive late endosomes do not contain LAMP1, unlike Rab7-positive late endosomes in fibroblasts (Yap et al., 2018). These results thus demonstrate that the "somatodendritic domain" is not homogeneous but contains distinct regions with functionally and molecularly distinct organelles. Most strikingly, degradative lysosomes are scarce in dendritic regions $>25 \mu \mathrm{m}$ away from the soma. Finally, overexpression of a dominantnegative Rab7 demonstrates that Rab7 activity is required to mobilize distal predegradative dendritic late endosomes for transport to the soma and degradation (Yap et al., 2018). Because the vast majority of dendritic LAMP1-positive endosomes are not degradative lysosomes, bulk degradation of short-lived dendritic membrane cargos requires Rab7-dependent transport in late endosomes to somatic lysosomes.

A similar observation of LAMP1-containing organelles deficient in lysosomal proteases was made by $\mathrm{Zu}-\mathrm{Hang}$ Sheng's group in distal axons of mammalian DRG and cortical neurons (Cheng et al., 2018). These findings clearly suggest that distal and proximal compartments in both axons and dendrites are distinct. The current data favor a model by which compartments mature toward late endosomal and lysosomal fates in both axons and dendrites, as they are transported toward the soma, and that they progressively acidify and gain lysosomal hydrolases as they approach the soma (Ferguson, 2018). This has been shown nicely in 
axons by several groups, including Ralph Nixon's group (Lee et al., 2011) and Shawn Ferguson's group (Gowrishankar et al., 2017). There are also intriguing data that transport and maturation of predegradative lysosomes in axons are impaired in Alzheimer's disease (AD) and could account for increased $\beta$-site APP cleaving enzyme 1 (BACE1)-dependent cleavage of amyloid precursor protein (APP) to the toxic $\beta$-amyloid (A $\beta$ ) (Gowrishankar et al., 2015). Finally, Juan Bonifacino's group reported differential acidity for LAMP1-containing organelles in proximal versus distal axons, which further supports the idea that LAMP1containing organelles in distal axons do not have high degradative capacity (Farías et al., 2017), and might thus be more accurately categorized as "lysosome-like" or "predegradative" immature lysosomes, similarly to the distinction made by Gowrishankar et al. (2015) for axonal "lysosome-like organelles."

Interestingly, live imaging studies in the Drosophila brain reveal two parallel pathways for degrading membrane proteins locally in axonal terminals: a Rab7-dependent pathway for plasma membrane proteins, and a Rab7-independent pathway for degrading synaptic proteins (Jin et al., 2018b), suggesting that some degradative substrates can be degraded distally in axons in distinct organelles. In addition, a cathepsin was identified in distal axons in this study. Along the same lines, degradative lysosomes might also be found near synapses in dendrites, albeit infrequently, and could perform activity-dependent degradation near synapses (Goo et al., 2017). Whether these rare synapse-near lysosomes are specialized to degrade a subset of cargos (such as glutamate receptors) is not known but would be consistent with our recent finding that bulk degradation requires retrograde transport to the soma where degradative lysosomes are abundant (Yap et al., 2018). Another study reports activity-dependent exocytosis of CathepsinB from lysosomes in spines, a very intriguing novel mechanism of how spine growth is promoted by activity (Padamsey et al., 2017). These findings highlight the complexities in the composition of endolysosomal compartments, raise the possibility that dendritic and axonal endolysosomes differ, and suggest that the field needs to develop additional tools and clarify the nomenclature to distinguish related, but functionally distinct compartments.

In addition to its importance in regulating bulk degradation, Rab7 has also been shown to be important in regulating the levels of receptors important during development, such as $\mathrm{N}$-cadherin during neuronal migration in corticogenesis (Kawauchi et al., 2010), TrkA trafficking during development of the peripheral nervous system (Ye et al., 2018), and synaptic function (Fernández-Monreal et al., 2012; T. Kim et al., 2017). Moreover, work in Drosophila shows a particular early sensitivity of neurons specifically to loss of Rab7 (Cherry et al., 2013). The regulated maturation of endosomal compartments is thus critical for regulating the levels of many membrane receptors critical to neuronal development, synaptogenesis and nervous system function.

\section{Endolysosomal trafficking in neurodegeneration}

Given the particular challenges neurons face in regulating intracellular trafficking and proteostasis, it is not surprising that defects in intracellular trafficking have been implicated in the pathogenesis of major neurodegenerative diseases. Below we discuss recent findings on the mechanisms of endolysosomal trafficking in neurodegeneration, using $\mathrm{AD}$, Menkes disease, and Parkinson's diseases as examples.

\section{Endocytic trafficking, Menkes disease, and Parkinson's disease}

Normal and disease mechanisms can be inferred from interactomes, comprehensive maps of the temporal, spatial, and/or genetic interactions established by wild-type and mutant versions of a gene or its products (Barabási and Oltvai, 2004; Vidal et al., 2011; Ghiassian et al., 2015). Here we discuss insights from the interactomes of the copper transporter ATP7A and the endosome localized Vacuolar Protein Sorting 35 (VPS35), a subunit of the retromer sorting complex. Mutations in these genes cause severe neurodegenerative disorders, Menkes disease and Parkinson's disease, respectively (OMIM 309400 and 300011 for ATP7A, OMIM 601501 and 614203 for VPS35). These diseases are conceptualized as distinct entities. However, commonalities in their interactomes suggest that their pathogeneses may have more in common than we currently suspect.

Loss-of-function mutations in ATP7A causes Menkes disease (OMIM 309400), a widespread neurodegeneration of forebrain neurons usually lethal in early life. (Menkes et al., 1962; Menkes, 1988, 1999; Lutsenko et al., 2007; Kaler, 2011; Zlatic et al., 2015). ATP7A mutations produce disease by preventing protein expression, impairing copper transport into the Golgi lumen, and/ or by halting ATP7A at different subcellular compartments along the exocytic and endocytic route (Vulpe et al., 1993; Petris and Mercer, 1999; B. E. Kim et al., 2003; Tümer, 2013; Yi and Kaler, 2015). This later observation suggests that genetic defects in sorting complexes necessary for ATP7A traffic should in part phenocopy ATP7A genetic defects.

ATP7A localizes to the Golgi apparatus at steady state and cycles between the cell surface and the Golgi complex via endosomes (Lutsenko et al., 2007; Kaler, 2011). This trafficking cycle requires multiple cytosolic sorting complexes, among them the retromer complex (Setty et al., 2008; Ryder et al., 2013; Steinberg et al., 2013; Gokhale et al., 2015; Phillips-Krawczak et al., 2015; Yi and Kaler, 2015; Comstra et al., 2017). The retromer complex is of interest to neurodegeneration mechanisms because mutations in several of its subunits (VPS35, VPS29, and VPS26A) cause Parkinson's disease in humans (Kumar et al., 2012; McMillan et al., 2017). The mechanism by which retromer complex mutations cause Parkinson's disease is intimately tied to the membrane protein cargos whose subcellular localization depends on the activity of the retromer complex. These cargos include, but are not limited to, the mannose-6-phospate receptor (IGFR2), ATG9A, LAMP2a (LAMP2), and synaptic neurotransmitter receptors (Seaman, 2004; Steinberg et al., 2013; McMillan et al., 2017). Retromer-dependent defects in the sorting of these cargos impair autophagy and chaperone-mediated-autophagy (Kaushik and Cuervo, 2012) and decrease the content of hydrolases in the lysosome lumen (Seaman, 2004; Kaushik and Cuervo, 2012; McMillan et al., 2017). These hydrolases are necessary for aggregate and damaged organelle disposal via autophagy pathways. Although ATP7A is a retromer cargo, ATP7A has not been considered as a contributor to Parkinson's pathogenesis (Ryder et al., 2013; Steinberg et al., 2013; Phillips-Krawczak et al., 2015; Small and Petsko, 2015; S. Wang and Bellen, 2015; Comstra et al., 2017; McMillan et al., 2017; Zhang et al., 2018).

Why should we care about the intersection between ATP7A, sorting complexes, and Parkinson's disease pathways? Alterations of copper content and copper buffering mechanisms are a common occurrence in sporadic cases of Parkinson's disease (Gaggelli et al., 2006; Davies et al., 2014; Lan et al., 2016). This is an important observation because copper induces $\alpha$ synuclein protein aggregation, protein and organelle oxidative damage, and 
perturbs mitochondrial function (Paik et al., 1999; Rasia et al., 2005; Zischka et al., 2011; Aboud et al., 2015). Genetic evidence also supports a connection between copper and Parkinson's disease. ATP7A genetically interacts with the Parkinson's and spastic paraplegia associated gene UCHL1, which encodes a deubiquitinating enzyme (Leroy et al., 1998; Bilguvar et al., 2013; Zlatic et al., 2018). The mitochondrion could be an organelle where defective ATP7A and retromer function could converge to cause or modulate neurodegeneration. This idea is supported by the observation that retromer function is required to maintain mitochondria morphology and function (Tang et al., 2015; W. Wang et al., 2016). Mitochondrial fragmentation and depolarization mark organelles for autophagic destruction, a pathway controlled by the Parkinson's disease genes pink and parkin (PARK2) (Pickrell and Youle, 2015; Pickles et al., 2018). This pink-parkin (PARK2) pathway is likely involved in retromer-dependent mechanism as indicated by genetic interactions between Drosophila Vps35 and parkin (Malik et al., 2015). Thus, similar to VPS35, it is possible that parkin (PARK2)- and pink-dependent mitophagy mechanisms may also be part of the ATP7A interactome. This raises the interesting hypothesis that possible mechanistic links, at the level of mitochondrial function or mitochondrial quality control, between clinically dissimilar diseases, such as Parkinson's disease, Menkes disease, and AD, may be more widespread than we have so far envisioned (C. L. Wang et al., 2012; Ye et al., 2015).

\section{Endolysosomal trafficking of APP and BACE1 and AD}

$\mathrm{AD}$ is an age-dependent neurodegenerative disease that is the most common cause of dementia among the elderly. More than $90 \%$ of $\mathrm{AD}$ cases are of the late-onset and sporadic form, LOAD, the causes of which remain unclear. One key pathological feature of the $\mathrm{AD}$ brain is extracellular plaques containing $\mathrm{A} \beta$, which is produced intracellularly through sequential cleavage of the APP by BACE1 and $\gamma$-secretase. The rate-limiting step for A $\beta$ generation is the physical convergence between APP and BACE1 in endosomes (Koo and Squazzo, 1994; Zou et al., 2007; Cirrito et al., 2008; Sannerud et al., 2011; U. Das et al., 2013; Sun and Roy, 2018). Because both APP and BACE1 are membrane proteins that traffic through the endolysosomal system, understanding their trafficking patterns within the endosomal pathways is critical for elucidating the mechanisms of AD pathogenesis.

Remarkably, a number of LOAD risk variants identified through genetic screens are of genes encoding regulators of endocytic trafficking (Bertram et al., 2007; Rogaeva et al., 2007; Harold et al., 2009; Hollingworth et al., 2011; Naj et al., 2011), including Bin1 and CD2AP (Guimas Almeida et al., 2018). Using a loss-of-function approach in primary mouse cortical neurons, it was recently reported that the regulation of trafficking of APP and BACE1 through early endosomes in axons is different from dendrites. APP endosomal sorting is dependent on CD2AP but only at dendritic endosomes, whereas BACE1 recycling is dependent on Bin1 predominantly in axonal endosomes. Bin 1 and CD2AP localization was polarized, while CD2AP was enriched in dendritic endosomes, and Bin 1 was in axonal endosomes (Ubelmann et al., 2017). This polarization translated into a preferential accumulation of $\mathrm{A} \beta 42$ in dendrites when CD2AP was knocked down and in axons when Bin 1 was knocked down. This differential regulation of APP processing in axons and dendrites had not been observed before. These studies shine a mechanistic spotlight on how neuronal cellular machinery could be causing AD cellular phenotypes.
Previous studies indicated that APP and BACE1 localize to both axons and dendrites with APP enriched in axons (Brunholz et al., 2012). APP and BACE1 endocytosis can occur from the axonal and dendritic plasma membrane (Simons et al., 1995; Yamazaki et al., 1996; Schneider et al., 2008; Sullivan et al., 2014; Niederst et al., 2015). APP proteolytic processing by BACE1 and $\gamma$-secretase can occur both in axons and in dendrites, being more prominent presynaptically (Buxbaum et al., 1998; Lyckman et al., 1998; Lazarov et al., 2002; Buggia-Prévot et al., 2013; DeBoer et al., 2014; Niederst et al., 2015). The secretion of newly formed A $\beta$ likely occurs more presynaptically, although it can also occur postsynaptically (Lazarov et al., 2002; Wei et al., 2010; DeBoer et al., 2014). Axonally secreted $A \beta$ contributes locally to presynaptic dysfunction and to extracellular amyloid deposition, but can also trigger spine loss and postsynaptic glutamate receptors endocytosis (Wei et al., 2010). Thus, a polarized increase of $\mathrm{A} \beta$ production may eventually lead to an initial presynaptic or postsynaptic dysfunction preceding a more generalized neuronal dysfunction.

The polarized production and secretion of $A \beta$ raise the intriguing possibility that proteins regulating cellular polarity are involved in this process. Indeed, recent studies have highlighted a role for the cell polarity regulator partitioning-defective 3 (Par3) in $A \beta$ production through modulating both APP and BACE1 trafficking. Interestingly, the effects of Par3 on APP and BACE1 trafficking are through two distinct mechanisms. Par3 regulates APP trafficking through the endocytic adaptor protein Numb (Sun et al., 2016). By contrast, Par3 and its binding partner atypical PKC (aPKC) regulate BACE1 retrograde endosome-to-TGN trafficking through PACS1 (Sun and Zhang, 2017). In the absence of Par3, both APP and BACE1 are enriched in the late endocytic compartments, leading to increased intracellular $A \beta$ accumulation (Sun et al., 2016; Sun and Zhang, 2017).

The endolysosomal trafficking of BACE1 is also differentially regulated in dendrites versus axons. Dendritic BACE1 undergoes unidirectional retrograde transport, which is regulated by the Eps-15-homology-domain-containing family proteins (BuggiaPrévot et al., 2013). By contrast, axonal BACE1 undergoes bidirectional transport in dynamic tubulo-vesicular carriers (Buggia-Prévot et al., 2014). Sorting of BACE1 to the axons is Rab11-dependent (Buggia-Prévot et al., 2014), and axonal BACE1 is retrogradely transported by the dynein adaptor Snapin in Rab7-positive late endosomes to the cell body for degradation in mature lysosomes (Ye and Cai, 2014; Ye et al., 2017). Finally, visualization of APP and BACE1 convergence through fluorescence complementation also confirms that APP and BACE1 trafficking are differentially regulated in dendrites and axons (U. Das et al., 2016).

\section{The autophagy-lysosome system in neuronal homeostasis and neurodegeneration}

Protein and organelle homeostasis requires cooperation between the endolysosomal system and autophagy. Autophagy is a cellular quality control pathway that is essential for neuronal function and viability (Yamamoto and Yue, 2014; Ariosa and Klionsky, 2016; Kulkarni and Maday, 2018). In this process, proteins and organelles targeted for destruction are engulfed and sequestered by autophagosomes, and delivered to lysosomes for breakdown by resident proteases (Mizushima and Komatsu, 2011; Weidberg et al., 2011; Feng et al., 2014). Degradation products can then be recycled to fuel new biosynthetic reactions. Autophagic cargos in neurons can include synaptic proteins and vesicles (Rowland et al., 2006; Hernandez et al., 2012; Shehata et al., 2012; Binotti et al., 2015; Lüningschrör et al., 2017; Nikoletopoulou et al., 2017; Ok- 
erlund et al., 2017; Nikoletopoulou and Tavernarakis, 2018), mitochondria (Cai et al., 2012; Maday et al., 2012; Ashrafi et al., 2014; Rangaraju et al., 2014; Wong and Holzbaur, 2014b; Xie et al., 2015; Ebrahimi-Fakhari et al., 2016), and pathogenic protein aggregates, such as cytoplasmic $\alpha$-synuclein aggregates (Tanik et al., 2013), mutant huntingtin aggregates (Wong and Holzbaur, 2014a), and amyloid $\beta$ peptides (Yu et al., 2005; Feng et al., 2017; Tammineni et al., 2017a). Thus, autophagy provides a constitutive mechanism to replenish cellular components, and also a dynamic response to cellular stress, such as nutrient deprivation, organelle damage, protein aggregation, and disease (Schneider and Cuervo, 2014).

Alterations in autophagy are associated with neurodevelopmental abnormalities and neurodegeneration (Tang et al., 2014; Dragich et al., 2016; Stavoe et al., 2016; Kulkarni and Maday, 2018; Li et al., 2018; Lieberman et al., 2018; Schäffner et al., 2018). Neuron-specific loss of autophagy is sufficient to induce neurodegeneration in mice (Hara et al., 2006; Komatsu et al., 2006; Komatsu et al., 2007; Nishiyama et al., 2007), and mutations in key autophagy genes lead to neurodegenerative disease in humans (Frake et al., 2015; M. Kim et al., 2016; Maday, 2016). Thus, evidence supports a neuroprotective role for autophagy in the nervous system. Our understanding of the mechanisms that regulate autophagy, particularly within each compartment of the neuron (e.g., axons vs dendrites vs the soma), however, are only beginning to be elucidated.

Autophagy in the axon follows a vectorial trajectory that delivers cargo from the distal axon to the soma. Axonal autophagosomes initiate largely in distal regions of the axon (Fig. 1) (Hollenbeck, 1993; Maday et al., 2012; Maday and Holzbaur, 2014; Cheng et al., 2015a; T. C. Wang et al., 2015; Soukup et al., 2016). Following formation, autophagosomes then undergo retrograde trafficking toward the soma, and this transport is coupled to their maturation into degradative compartments (Hollenbeck, 1993; Yue, 2007; Lee et al., 2011; Maday et al., 2012; Maday and Holzbaur, 2014; Cheng et al., 2015a; T. Wang et al., 2015; Tammineni et al., 2017a). Once in the soma, autophagosomes are confined within the somatodendritic domain (Maday and Holzbaur, 2016), which likely facilitates cargo degradation by promoting fusion with proteolytically active lysosomes that are enriched in this region (Lee et al., 2011; Gowrishankar et al., 2015; Xie et al., 2015; Tammineni et al., 2017b; Cheng et al., 2018; Yap et al., 2018). Thus, the soma contains multiple populations of autophagosomes at different maturation states, including axonally derived autophagosomes combined with those generated locally (Maday and Holzbaur, 2016). Inhibition of lysosome function results in accumulation of autophagosomes specifically within the soma and not in the axon (Maday and Holzbaur, 2016), indicating that the soma is the primary site of autophagosome deposition and cargo degradation. In contrast to the unidirectional motility exhibited by axonal autophagosomes, dendritic autophagosomes undergo bidirectional motility, or oscillate within a confined region along the dendritic shaft (Fig. 1) (Maday and Holzbaur, 2014). In total, emerging evidence reveals compartment-specific mechanisms for autophagosome trafficking that may facilitate a range of functions within the neuron, particularly at sites far from the soma (Maday, 2016; Kulkarni and Maday, 2018).

Retrograde transport of LEs/amphisomes is mediated by dynein motors. A number of studies proposed that the RILP-Rab7ORP1L complex regulates dynein-driven retrograde transport of autophagosomes and endolysosomes (Johansson et al., 2007; Progida et al., 2007; Rocha et al., 2009; van der Kant et al., 2013;
Wijdeven et al., 2016). In particular, Rab7 interacts with RILP and ORP1L to form a RILP-Rab7-ORP1L complex, which mediates dynein motor recruitment through RILP interaction with p150Glued, a component of dynactin complex. While this model has been well tested in non-neuronal cells, such as HeLa and MelJuSo cells, the evidence of its involvement in retrograde axonal transport in neurons is still lacking. Snapin was proposed to serve as an adaptor of dynein motors, which directly interacts with the dynein intermediate chain. Snapin localizes on the late endosomal membrane through a hydrophobic region at its amino terminal and direct interaction with dynein motors mediates the recruitment of dynein motors to LEs, enabling longdistance transport of LEs from distal axons toward the soma (Cai et al., 2010; Cai and Sheng, 2011). Furthermore, through fusion with LEs to form amphisomes, newly generated autophagosomes in axons and presynaptic terminals gain retrograde transport motility by recruiting LE-loaded dynein-Snapin motor-adaptor complex (Cheng et al., 2015a). Such a mechanism facilitates the efficient clearance of autophagic cargos within lysosomes in the soma, thereby reducing autophagic stress in distal axons (Cheng et al., 2015a, b). Intriguingly, snapin deficiency did not impact the association of p150Glued (dynactin complex) with these organelles (Cai et al., 2010; Cheng et al., 2015a; Ye et al., 2017). This suggests that dynein-Snapin-mediated retrograde transport is independent of the dynactin complex, which is different from the mechanism mediated by the RILP-Rab7-ORP1L complex. Moreover, JIP3 has been shown to be involved in the regulation of lysosome transport through various mechanisms (Drerup and Nechiporuk, 2013; Edwards et al., 2013; Edwards et al., 2015; Gowrishankar et al., 2017). There is no evidence showing the direct involvement of JIP3 in dynein-mediated retrograde transport of LEs /amphisomes. Studies in zebrafish excluded the possibility that JIP3 regulates retrograde transport of LEs and autophagosomes (Drerup and Nechiporuk, 2013). Therefore, Rab7 or Snapin-mediated mechanisms are different from JIP3associated pathways and likely act in parallel.

The accumulation of misfolded protein is associated with the pathogenesis of various neurodegenerative diseases (Cushman et al., 2010), which underscores the importance of proteostasis pathways in maintaining neuronal function and survival. In particular, autophagy-lysosomal dysfunction has been implicated as one of the main cellular defects contributing to the onset and progression of $\mathrm{AD}$ (Nixon, 2013). In AD brains, autophagic vacuoles accumulate massively within dystrophic neurites (Nixon et al., 2005). This raises a fundamental question as to whether defects in autophagic clearance contribute to $\mathrm{AD}$-associated autophagic stress. Recent studies revealed that retrograde transport of amphisomes is impaired, leading to aberrant accumulation of amphisomes in axons and presynaptic terminals in the brains of AD-related mutant human APP (hAPP) transgenic (Tg) mice and $\mathrm{AD}$ patients (Tammineni et al., 2017a). Soluble A $\beta$ oligomers are found to be enriched in axons and interact with dynein motors. This interaction interferes with the coupling of the dynein motor with its adaptor Snapin, interrupting the recruitment of dynein motors to amphisomes. Such a defect disrupts dyneindriven retrograde transport of amphisomes, trapping them in distal axons and thus impairing their degradation within lysosomes in the soma (Tammineni et al., 2017a). Accordingly, deletion of snapin in mice causes AD-like axonal autophagic stress, whereas overexpressing Snapin in hAPP neurons reduces autophagic accumulation at presynaptic terminals by enhancing amphisome retrograde transport (Tammineni and Cai, 2017; Tammineni et al., 2017a). 
Interestingly, the $\beta$-secretase BACE1 is concentrated in amphisomes, accumulating in the distal axons of $\mathrm{AD}$ neurons. In $\mathrm{AD}$ neurons, impaired retrograde transport of amphisomes augments autophagic retention of BACE1 in axons, exacerbating $\beta$-cleavage of APP and thus $A \beta$-induced synaptotoxicity by $\mathrm{A} \beta$ overproduction (Feng et al., 2017). This phenotype can be reversed by Snapin-enhanced retrograde transport through facilitating BACE1 trafficking to somatic lysosomes for degradation (Feng et al., 2017). Moreover, elevated Snapin expression via stereotactic hippocampal injections of adeno-associated virus particles in mutant hAPP Tg mouse brains decreases synaptic A $\beta$ levels and ameliorates synapse loss, mitigating cognitive impairments associated with hAPP mice (Ye et al., 2017). Together, these studies provide new mechanistic insights into AD-linked autophagic pathology, and autophagy-mediated regulation of BACE1 turnover and APP processing through Snapin-mediated dynein-driven retrograde axonal transport. In addition, these findings build a foundation for future development of potential $\mathrm{AD}$ therapeutic strategies by restoring retrograde transport of amphisomes, and suggest a potential approach of modulating A $\beta$ levels and attenuating synaptic deficits associated with $\mathrm{AD}$.

\section{Conclusions and future outlook}

The endolysosomal system plays a key role in regulating neuronal proteostasis, and defects within the trafficking pathways have been implicated a number of neurodevelopmental and neurodegenerative disorders. While endolysosomal trafficking has been studied extensively in non-neuronal cells, recent studies in neurons have highlighted the importance of understanding the basic cell biology of intracellular trafficking within the context of neurons. Clearly, neurons have adapted their endolysosomal trafficking system to accommodate their morphological complexity, their high levels of activity, and longevity, and trafficking mechanisms are differentially regulated in dendrites, axons, and microcompartments, such as dendritic spines.

While great progress has been made in recent years, a number of important questions remain. For example, although mature lysosomes with high degradative capacity are found primarily in cell bodies, local degradation of cargos in axons and dendrites can occur (Jin et al., 2018b). Yet, it remains unclear which cargos are sorted locally in distal axons and dendrites to be degraded and recycled locally, and which cargos are transported toward the soma for degradation. The functional implications of local versus central degradation of different cargos are also unknown. Similarly, while recent studies have revealed differential regulation of dendritic versus axonal transport, how neurons establish and maintain these distinct regulatory mechanisms in different neuronal compartments remains largely unknown. In addition, recent studies have described contact sites between endosomes and ER as well as mitochondria (Rowland et al., 2014; Raiborg et al., 2015a, b; A. Das et al., 2016; Luarte et al., 2018), but there is a dearth of knowledge regarding the functional role of these contact sites in endosomal dynamics, lipid composition, signal transduction, and possibly calcium buffering.

Moreover, how is directional transport organized in dendrites? While axonal transport is relatively well studied, much less is known about the regulation of dendritic trafficking. Dendrites are also very long and require organized transport to ensure proper localization of receptors and regulated turnover. This holds for synaptic receptors whose surface density at postsynaptic sites sets synaptic strength, but also for receptors that signal during development. One critical aspect of both axonal and dendritic transport is directionality because the receptors need to be deliv- ered either in an anterograde direction toward the axon terminals or distal dendritic segments, or be returned back toward the soma for degradation or signaling. The problem of how directional transport is organized has been solved on a conceptual level in the axon: microtubules are uniformly oriented with their plus ends toward the axon tip. Therefore, kinesin motors are responsible for anterograde axonal transport and dynein motors drive retrograde transport. In dendrites, such a simple solution to the problem of directionality did not present itself: microtubules are of mixed polarity, and either kinesin or dynein could in principle be responsible for retrograde transport of degradative cargos from distal dendrites to somatic lysosomes. Interestingly, a recent study shows that, in dendrites, stable and acetylated microtubules are oriented minus-end out, whereas dynamic, tyrosinated microtubules are of the opposite direction (Tas et al., 2017). Thus, preferential binding of acetylated versus tyrosinated microtubules by motor proteins can lead to directional transport within dendrites. In addition, dendritic microtubules organize into bundles of uniform polarity, which can locally bias the directionality of transport (Tas et al., 2017). However, how neurons regulate retrograde transport in dendrites still remains unclear. The hunt for understanding the machinery for directional dendritic transport thus continues!

Finally, the extent to which interactions between neurons and surrounding glia impact proteostasis networks in the brain is largely unknown (Kulkarni et al., 2018). Preliminary studies support a potential role for glia in regulating neuronal autophagy (Alirezaei et al., 2008; Gan et al., 2012; Madill et al., 2017). Further, glial autophagy may have profound effects on neuronal function, connectivity, and response to stress induced by injury (Gomez-Sanchez et al., 2015; Jang et al., 2016; H. J. Kim et al., 2017). Because many neurodegenerative diseases may propagate through a prion-like cell-to-cell transfer of disease-associated proteins (Cushman et al., 2010; Luk et al., 2012), it remains critical to define the precise role of endolysosomal trafficking and autophagy in both neurons and glia, particularly in response to neurotoxic stress (Davis et al., 2014; Melentijevic et al., 2017; Spiller et al., 2018).

\section{References}

Aboud AA, Tidball AM, Kumar KK, Neely MD, Han B, Ess KC, Hong CC, Erikson KM, Hedera P, Bowman AB (2015) PARK2 patient neuroprogenitors show increased mitochondrial sensitivity to copper. Neurobiol Dis 73:204-212. CrossRef Medline

Alirezaei M, Kiosses WB, Flynn CT, Brady NR, Fox HS (2008) Disruption of neuronal autophagy by infected microglia results in neurodegeneration. PLoS One 3:e2906. CrossRef Medline

Ariosa AR, Klionsky DJ (2016) Autophagy core machinery: overcoming spatial barriers in neurons. J Mol Med (Berl) 94:1217-1227. CrossRef Medline

Ashrafi G, Schlehe JS, LaVoie MJ, Schwarz TL (2014) Mitophagy of damaged mitochondria occurs locally in distal neuronal axons and requires PINK1 and parkin. J Cell Biol 206:655-670. CrossRef Medline

Barabási AL, Oltvai ZN (2004) Network biology: understanding the cell's functional organization. Nat Rev Genet 5:101-113. CrossRef Medline

Bertram L, McQueen MB, Mullin K, Blacker D, Tanzi RE (2007) Systematic meta-analyses of Alzheimer Disease Genetic Association studies: the AlzGene database. Nat Genet 39:17-23. CrossRef Medline

Bilguvar K, Tyagi NK, Ozkara C, Tuysuz B, Bakircioglu M, Choi M, Delil S, Caglayan AO, Baranoski JF, Erturk O, Yalcinkaya C, Karacorlu M, Dincer A, Johnson MH, Mane S, Chandra SS, Louvi A, Boggon TJ, Lifton RP, Horwich AL, et al. (2013) Recessive loss of function of the neuronal ubiquitin hydrolase UCHL1 leads to early-onset progressive neurodegeneration. Proc Natl Acad Sci U S A 110:3489-3494. CrossRef Medline

Binotti B, Pavlos NJ, Riedel D, Wenzel D, Vorbrüggen G, Schalk AM, Kühnel K, Boyken J, Erck C, Martens H, Chua JJ, Jahn R (2015) The GTPase 
Rab26 links synaptic vesicles to the autophagy pathway. Elife 4:e05597. CrossRef Medline

Brunholz S, Sisodia S, Lorenzo A, Deyts C, Kins S, Morfini G (2012) Axonal transport of APP and the spatial regulation of APP cleavage and function in neuronal cells. Exp Brain Res 217:353-364. CrossRef Medline

Buggia-Prévot V, Fernandez CG, Udayar V, Vetrivel KS, Elie A, Roseman J, Sasse VA, Lefkow M, Meckler X, Bhattacharyya S, George M, Kar S, Bindokas VP, Parent AT, Rajendran L, Band H, Vassar R, Thinakaran G (2013) A function for EHD family proteins in unidirectional retrograde dendritic transport of BACE1 and Alzheimer's disease abeta production. Cell Rep 5:1552-1563. CrossRef Medline

Buggia-Prévot V, Fernandez CG, Riordan S, Vetrivel KS, Roseman J, Waters J, Bindokas VP, Vassar R, Thinakaran G (2014) Axonal BACE1 dynamics and targeting in hippocampal neurons: a role for Rab11 GTPase. Mol Neurodegener 9:1. CrossRef Medline

Buxbaum JD, Thinakaran G, Koliatsos V, O'Callahan J, Slunt HH, Price DL, Sisodia SS (1998) Alzheimer amyloid protein precursor in the rat hippocampus: transport and processing through the perforant path. J Neurosci 18:9629-9637. CrossRef Medline

Cai Q, Sheng ZH (2011) Uncovering the role of snapin in regulating autophagy-lysosomal function. Autophagy 7:445-447. CrossRef Medline

Cai Q, Lu L, Tian JH, Zhu YB, Qiao H, Sheng ZH (2010) Snapin-regulated late endosomal transport is critical for efficient autophagy-lysosomal function in neurons. Neuron 68:73-86. CrossRef Medline

Cai Q, Zakaria HM, Simone A, Sheng ZH (2012) Spatial parkin translocation and degradation of damaged mitochondria via mitophagy in live cortical neurons. Curr Biol 22:545-552. CrossRef Medline

Cajigas IJ, Will T, Schuman EM (2010) Protein homeostasis and synaptic plasticity. EMBO J 29:2746-2752. CrossRef Medline

Cheng XT, Zhou B, Lin MY, Cai Q, Sheng ZH (2015a) Axonal autophagosomes recruit dynein for retrograde transport through fusion with late endosomes. J Cell Biol 209:377-386. CrossRef Medline

Cheng XT, Zhou B, Lin MY, Cai Q, Sheng ZH (2015b) Axonal autophagosomes use the ride-on service for retrograde transport toward the soma. Autophagy 11:1434-1436. CrossRef Medline

Cheng XT, Xie YX, Zhou B, Huang N, Farfel-Becker T, Sheng ZH (2018) Characterization of LAMP1-labeled nondegradative lysosomal and endocytic compartments in neurons. J Cell Biol 217:3127-3139. CrossRef Medline

Cherry S, Jin EJ, Ozel MN, Lu Z, Agi E, Wang D, Jung WH, Epstein D, Meinertzhagen IA, Chan CC, Hiesinger PR (2013) Charcot-MarieTooth $2 \mathrm{~B}$ mutations in rab7 cause dosage-dependent neurodegeneration due to partial loss of function. Elife 2:e01064. CrossRef Medline

Cirrito JR, Kang JE, Lee J, Stewart FR, Verges DK, Silverio LM, Bu G, Mennerick S, Holtzman DM (2008) Endocytosis is required for synaptic activity-dependent release of amyloid-beta in vivo. Neuron 58:42-51. CrossRef Medline

Comstra HS, McArthy J, Rudin-Rush S, Hartwig C, Gokhale A, Zlatic SA, Blackburn JB, Werner E, Petris M, D'Souza P, Panuwet P, Barr DB, Lupashin V, Vrailas-Mortimer A, Faundez V (2017) The interactome of the copper transporter ATP7A belongs to a network of neurodevelopmental and neurodegeneration factors. Elife 6:e24722. CrossRef Medline

Cushman M, Johnson BS, King OD, Gitler AD, Shorter J (2010) Prion-like disorders: blurring the divide between transmissibility and infectivity. J Cell Sci 123:1191-1201. CrossRef Medline

Das A, Nag S, Mason AB, Barroso MM (2016) Endosome-mitochondria interactions are modulated by iron release from transferrin. J Cell Biol 214:831-845. CrossRef Medline

Das U, Scott DA, Ganguly A, Koo EH, Tang Y, Roy S (2013) Activityinduced convergence of APP and BACE-1 in acidic microdomains via an endocytosis-dependent pathway. Neuron 79:447-460. CrossRef Medline

Das U, Wang L, Ganguly A, Saikia JM, Wagner SL, Koo EH, Roy S (2016) Visualizing APP and BACE-1 approximation in neurons yields insight into the amyloidogenic pathway. Nat Neurosci 19:55-64. CrossRef Medline

Davies KM, Bohic S, Carmona A, Ortega R, Cottam V, Hare DJ, Finberg JP, Reyes S, Halliday GM, Mercer JF, Double KL (2014) Copper pathology in vulnerable brain regions in Parkinson's disease. Neurobiol Aging 35: 858-866. CrossRef Medline

Davis CH, Kim KY, Bushong EA, Mills EA, Boassa D, Shih T, Kinebuchi M, Phan S, Zhou Y, Bihlmeyer NA, Nguyen JV, Jin Y, Ellisman MH, Marsh-
Armstrong N (2014) Transcellular degradation of axonal mitochondria. Proc Natl Acad Sci U S A 111:9633-9638. CrossRef Medline

DeBoer SR, Dolios G, Wang R, Sisodia SS (2014) Differential release of betaamyloid from dendrite- versus axon-targeted APP. J Neurosci 34:1231312327. CrossRef Medline

Dragich JM, Kuwajima T, Hirose-Ikeda M, Yoon MS, Eenjes E, Bosco JR, Fox LM, Lystad AH, Oo TF, Yarygina O, Mita T, Waguri S, Ichimura Y, Komatsu M, Simonsen A, Burke RE, Mason CA, Yamamoto A (2016) Autophagy linked FYVE (Alfy/WDFY3) is required for establishing neuronal connectivity in the mammalian brain. Elife 5:e14810. CrossRef Medline

Drerup CM, Nechiporuk AV (2013) JNK-interacting protein 3 mediates the retrograde transport of activated c-Jun $\mathrm{N}$-terminal kinase and lysosomes. PLoS Genet 9:e1003303. CrossRef Medline

Ebrahimi-Fakhari D, Saffari A, Wahlster L, Di Nardo A, Turner D, Lewis TL Jr, Conrad C, Rothberg JM, Lipton JO, Kölker S, Hoffmann GF, Han MJ, Polleux F, Sahin M (2016) Impaired mitochondrial dynamics and mitophagy in neuronal models of tuberous sclerosis complex. Cell Rep 17: 1053-1070. CrossRef Medline

Edwards SL, Yu SC, Hoover CM, Phillips BC, Richmond JE, Miller KG (2013) An organelle gatekeeper function for Caenorhabditis elegans UNC-16 (JIP3) at the axon initial segment. Genetics 194:143-161. CrossRef Medline

Edwards SL, Morrison LM, Yorks RM, Hoover CM, Boominathan S, Miller KG (2015) UNC-16 (JIP3) acts through synapse-assembly proteins to inhibit the active transport of cell soma organelles to Caenorhabditis elegans motor neuron axons. Genetics 201:117-141. CrossRef Medline

Farías GG, Guardia CM, De Pace R, Britt DJ, Bonifacino JS (2017) BORC/ kinesin-1 ensemble drives polarized transport of lysosomes into the axon. Proc Natl Acad Sci U S A 114:E2955-E2964. CrossRef Medline

Feng T, Tammineni P, Agrawal C, Jeong YY, Cai Q (2017) Autophagymediated regulation of BACE1 protein trafficking and degradation. J Biol Chem 292:1679-1690. CrossRef Medline

Feng Y, He D, Yao Z, Klionsky DJ (2014) The machinery of macroautophagy. Cell Res 24:24-41. CrossRef Medline

Ferguson SM (2018) Axonal transport and maturation of lysosomes. Curr Opin Neurobiol 51:45-51. CrossRef Medline

Fernández-Monreal M, Brown TC, Royo M, Esteban JA (2012) The balance between receptor recycling and trafficking toward lysosomes determines synaptic strength during long-term depression. J Neurosci 32:1320013205. CrossRef Medline

Frake RA, Ricketts T, Menzies FM, Rubinsztein DC (2015) Autophagy and neurodegeneration. J Clin Invest 125:65-74. CrossRef Medline

Gaggelli E, Kozlowski H, Valensin D, Valensin G (2006) Copper homeostasis and neurodegenerative disorders (Alzheimer's, prion, and Parkinson's diseases and amyotrophic lateral sclerosis). Chem Rev 106:1995-2044. CrossRef Medline

Gan L, Vargas MR, Johnson DA, Johnson JA (2012) Astrocyte-specific overexpression of $\mathrm{Nrf2}$ delays motor pathology and synuclein aggregation throughout the CNS in the alpha-synuclein mutant (A53T) mouse model. J Neurosci 32:17775-17787. CrossRef Medline

Ghiassian SD, Menche J, Barabási AL (2015) A DIseAse MOdule Detection (DIAMOnD) algorithm derived from a systematic analysis of connectivity patterns of disease proteins in the human interactome. PLoS Comput Biol 11:e1004120. CrossRef Medline

Gokhale A, Vrailas-Mortimer A, Larimore J, Comstra HS, Zlatic SA, Werner E, Manvich DF, Iuvone PM, Weinshenker D, Faundez V (2015) Neuronal copper homeostasis susceptibility by genetic defects in dysbindin, a schizophrenia susceptibility factor. Hum Mol Genet 24:5512-5523. CrossRef Medline

Gomez-Sanchez JA, Carty L, Iruarrizaga-Lejarreta M, Palomo-Irigoyen M, Varela-Rey M, Griffith M, Hantke J, Macias-Camara N, Azkargorta M, Aurrekoetxea I, De Juan VG, Jefferies HB, Aspichueta P, Elortza F, Aransay AM, Martínez-Chantar ML, Baas F, Mato JM, Mirsky R, Woodhoo A, et al. (2015) Schwann cell autophagy, myelinophagy, initiates myelin clearance from injured nerves. J Cell Biol 210:153-168. CrossRef Medline

Goo MS, Sancho L, Slepak N, Boassa D, Deerinck TJ, Ellisman MH, Bloodgood BL, Patrick GN (2017) Activity-dependent trafficking of lysosomes in dendrites and dendritic spines. J Cell Biol 216:2499-2513. CrossRef Medline

Gowrishankar S, Yuan P, Wu Y, Schrag M, Paradise S, Grutzendler J, De Camilli P, Ferguson SM (2015) Massive accumulation of luminal 
protease-deficient axonal lysosomes at Alzheimer's disease amyloid plaques. Proc Natl Acad Sci U S A 112:E3699-E3708. CrossRef Medline

Gowrishankar S, Wu Y, Ferguson SM (2017) Impaired JIP3-dependent axonal lysosome transport promotes amyloid plaque pathology. J Cell Biol 216:3291-3305. CrossRef Medline

Guimas Almeida C, Sadat Mirfakhar F, Perdigão C, Burrinha T (2018) Impact of late-onset Alzheimer's genetic risk factors on beta-amyloid endocytic production. Cell Mol Life Sci 75:2577-2589. CrossRef Medline

Hara T, Nakamura K, Matsui M, Yamamoto A, Nakahara Y, SuzukiMigishima R, Yokoyama M, Mishima K, Saito I, Okano H, Mizushima N (2006) Suppression of basal autophagy in neural cells causes neurodegenerative disease in mice. Nature 441:885-889. CrossRef Medline

Harold D, Abraham R, Hollingworth P, Sims R, Gerrish A, Hamshere ML, Pahwa JS, Moskvina V, Dowzell K, Williams A, Jones N, Thomas C, Stretton A, Morgan AR, Lovestone S, Powell J, Proitsi P, Lupton MK, Brayne C, Rubinsztein DC, et al. (2009) Genome-wide association study identifies variants at CLU and PICALM associated with Alzheimer's disease. Nat Genet 41:1088-1093. CrossRef Medline

Harris JJ, Attwell D (2012) The energetics of CNS white matter. J Neurosci 32:356-371. CrossRef Medline

Heo S, Diering GH, Na CH, Nirujogi RS, Bachman JL, Pandey A, Huganir RL (2018) Identification of long-lived synaptic proteins by proteomic analysis of synaptosome protein turnover. Proc Natl Acad Sci U S A 115: E3827-E3836. CrossRef Medline

Hernandez D, Torres CA, Setlik W, Cebrián C, Mosharov EV, Tang G, Cheng HC, Kholodilov N, Yarygina O, Burke RE, Gershon M, Sulzer D (2012) Regulation of presynaptic neurotransmission by macroautophagy. Neuron 74:277-284. CrossRef Medline

Hollenbeck PJ (1993) Products of endocytosis and autophagy are retrieved from axons by regulated retrograde organelle transport. J Cell Biol 121: 305-315. CrossRef Medline

Hollingworth P, Harold D, Sims R, Gerrish A, Lambert JC, Carrasquillo MM, Abraham R, Hamshere ML, Pahwa JS, Moskvina V, Dowzell K, Jones N, Stretton A, Thomas C, Richards A, Ivanov D, Widdowson C, Chapman J, Lovestone S, Powell J, et al. (2011) Common variants at ABCA7, MS4A6A/MS4A4E, EPHA1, CD33 and CD2AP are associated with Alzheimer's disease. Nat Genet 43:429-435. CrossRef Medline

Jang SY, Shin YK, Park SY, Park JY, Lee HJ, Yoo YH, Kim JK, Park HT (2016) Autophagic myelin destruction by Schwann cells during Wallerian degeneration and segmental demyelination. Glia 64:730-742. CrossRef Medline

Jin EJ, Kiral FR, Hiesinger PR (2018a) The where, what, and when of membrane protein degradation in neurons. Dev Neurobiol 78:283-297. CrossRef Medline

Jin EJ, Kiral FR, Ozel MN, Burchardt LS, Osterland M, Epstein D, Wolfenberg H, Prohaska S, Hiesinger PR (2018b) Live observation of two parallel membrane degradation pathways at axon terminals. Curr Biol 28:10271038.e4. CrossRef Medline

Johansson M, Rocha N, Zwart W, Jordens I, Janssen L, Kuijl C, Olkkonen VM, Neefjes J (2007) Activation of endosomal dynein motors by stepwise assembly of Rab7-RILP-p150Glued, ORP1L, and the receptor betall spectrin. J Cell Biol 176:459-471. CrossRef Medline

Kaler SG (2011) ATP7A-related copper transport diseases: emerging concepts and future trends. Nat Rev Neurol 7:15-29. CrossRef Medline

Kaushik S, Cuervo AM (2012) Chaperone-mediated autophagy: a unique way to enter the lysosome world. Trends Cell Biol 22:407-417. CrossRef Medline

Kawauchi T, Sekine K, Shikanai M, Chihama K, Tomita K, Kubo K, Nakajima K, Nabeshima Y, Hoshino M (2010) Rab GTPases-dependent endocytic pathways regulate neuronal migration and maturation through $\mathrm{N}$-cadherin trafficking. Neuron 67:588-602. CrossRef Medline

Kim BE, Smith K, Petris MJ (2003) A copper treatable Menkes disease mutation associated with defective trafficking of a functional Menkes copper ATPase. J Med Genet 40:290-295. CrossRef Medline

Kim HJ, Cho MH, Shim WH, Kim JK, Jeon EY, Kim DH, Yoon SY (2017a) Deficient autophagy in microglia impairs synaptic pruning and causes social behavioral defects. Mol Psychiatry 22:1576-1584. CrossRef Medline

Kim M, Sandford E, Gatica D, Qiu Y, Liu X, Zheng Y, Schulman BA, Xu J, Semple I, Ro SH, Kim B, Mavioglu RN, Tolun A, Jipa A, Takats S, Karpati M, Li JZ, Yapici Z, Juhasz G, Lee JH, et al. (2016) Mutation in ATG5 reduces autophagy and leads to ataxia with developmental delay. Elife 5:e12245. CrossRef Medline

Kim T, Yamamoto Y, Tanaka-Yamamoto K (2017b) Timely regulated sorting from early to late endosomes is required to maintain cerebellar longterm depression. Nat Commun 8:401. CrossRef Medline

Kiral FR, Kohrs FE, Jin EJ, Hiesinger PR (2018) Rab GTPases and membrane trafficking in neurodegeneration. Curr Biol 28:R471-R486. CrossRef Medline

Komatsu M, Waguri S, Chiba T, Murata S, Iwata J, Tanida I, Ueno T, Koike M, Uchiyama Y, Kominami E, Tanaka K (2006) Loss of autophagy in the central nervous system causes neurodegeneration in mice. Nature 441: 880-884. CrossRef Medline

Komatsu M, Wang QJ, Holstein GR, Friedrich VL Jr, Iwata J, Kominami E, Chait BT, Tanaka K, Yue Z (2007) Essential role for autophagy protein Atg7 in the maintenance of axonal homeostasis and the prevention of axonal degeneration. Proc Natl Acad Sci U S A 104:14489-14494. CrossRef Medline

Koo EH, Squazzo SL (1994) Evidence that production and release of amyloid beta-protein involves the endocytic pathway. J Biol Chem 269: 17386-17389. Medline

Kulkarni A, Chen J, Maday S (2018) Neuronal autophagy and intercellular regulation of homeostasis in the brain. Curr Opin Neurobiol 51:29-36. CrossRef Medline

Kulkarni VV, Maday S (2018) Compartment-specific dynamics and functions of autophagy in neurons. Dev Neurobiol 78:298-310. CrossRef Medline

Kumar KR, Weissbach A, Heldmann M, Kasten M, Tunc S, Sue CM, Svetel M, Kostic VS, Segura-Aguilar J, Ramirez A, Simon DK, Vieregge P, Münte TF, Hagenah J, Klein C, Lohmann K (2012) Frequency of the D620N mutation in VPS35 in Parkinson disease. Arch Neurol 69:1360-1364. CrossRef Medline

Lan AP, Chen J, Chai ZF, Hu Y (2016) The neurotoxicity of iron, copper and cobalt in Parkinson's disease through ROS-mediated mechanisms. Biometals 29:665-678. CrossRef Medline

Lazarov O, Lee M, Peterson DA, Sisodia SS (2002) Evidence that synaptically released beta-amyloid accumulates as extracellular deposits in the hippocampus of transgenic mice. J Neurosci 22:9785-9793. CrossRef Medline

Lee S, Sato Y, Nixon RA (2011) Lysosomal proteolysis inhibition selectively disrupts axonal transport of degradative organelles and causes an Alzheimer's-like axonal dystrophy. J Neurosci 31:7817-7830. CrossRef Medline

Leroy E, Boyer R, Auburger G, Leube B, Ulm G, Mezey E, Harta G, Brownstein MJ, Jonnalagada S, Chernova T, Dehejia A, Lavedan C, Gasser T, Steinbach PJ, Wilkinson KD, Polymeropoulos MH (1998) The ubiquitin pathway in Parkinson's disease. Nature 395:451-452. CrossRef Medline

Li X, Han X, Tu X, Zhu D, Feng Y, Jiang T, Yang Y, Qu J, Chen JG (2018) An autism-related, nonsense Foxp1 mutant induces autophagy and delays radial migration of the cortical neurons. Cereb Cortex. Advance online publication. Retrieved Aug. 15, 2018. doi: 10.1093/cercor/bhy185. CrossRef Medline

Lieberman OJ, McGuirt AF, Tang G, Sulzer D (2018) Roles for neuronal and glial autophagy in synaptic pruning during development. Neurobiol Dis. Advance online publication. Retrieved Apr. 28, 2018. doi: 10.1016/ j.nbd.2018.04.017. CrossRef Medline

Luarte A, Cornejo VH, Bertin F, Gallardo J, Couve A (2018) The axonal endoplasmic reticulum: one organelle-many functions in development, maintenance, and plasticity. Dev Neurobiol 78:181-208. CrossRef Medline

Luk KC, Kehm V, Carroll J, Zhang B, O'Brien P, Trojanowski JQ, Lee VM (2012) Pathological alpha-synuclein transmission initiates Parkinsonlike neurodegeneration in nontransgenic mice. Science 338:949-953. CrossRef Medline

Lüningschrör P, Binotti B, Dombert B, Heimann P, Perez-Lara A, Slotta C, Thau-Habermann N, R von Collenberg C, Karl F, Damme M, Horowitz A, Maystadt I, Füchtbauer A, Füchtbauer EM, Jablonka S, Blum R, Üçeyler N, Petri S, Kaltschmidt B, Jahn R, et al. (2017) Plekhg5-regulated autophagy of synaptic vesicles reveals a pathogenic mechanism in motoneuron disease. Nat Commun 8:678. CrossRef Medline

Lutsenko S, Barnes NL, Bartee MY, Dmitriev OY (2007) Function and reg- 
ulation of human copper-transporting ATPases. Physiol Rev 87:10111046. CrossRef Medline

Lyckman AW, Confaloni AM, Thinakaran G, Sisodia SS, Moya KL (1998) Post-translational processing and turnover kinetics of presynaptically targeted amyloid precursor superfamily proteins in the central nervous system. J Biol Chem 273:11100-11106. CrossRef Medline

Maday S (2016) Mechanisms of neuronal homeostasis: autophagy in the axon. Brain Res 1649:143-150. CrossRef Medline

Maday S, Holzbaur EL (2014) Autophagosome biogenesis in primary neurons follows an ordered and spatially regulated pathway. Dev Cell 30:7185. CrossRef Medline

Maday S, Holzbaur EL (2016) Compartment-specific regulation of autophagy in primary neurons. J Neurosci 36:5933-5945. CrossRef Medline

Maday S, Wallace KE, Holzbaur EL (2012) Autophagosomes initiate distally and mature during transport toward the cell soma in primary neurons. J Cell Biol 196:407-417. CrossRef Medline

Madill M, McDonagh K, Ma J, Vajda A, McLoughlin P, O’Brien T, Hardiman O, Shen S (2017) Amyotrophic lateral sclerosis patient iPSC-derived astrocytes impair autophagy via non-cell autonomous mechanisms. Mol Brain 10:22. CrossRef Medline

Malik BR, Godena VK, Whitworth AJ (2015) VPS35 pathogenic mutations confer no dominant toxicity but partial loss of function in Drosophila and genetically interact with parkin. Hum Mol Genet 24:6106-6117. CrossRef Medline

McMillan KJ, Korswagen HC, Cullen PJ (2017) The emerging role of retromer in neuroprotection. Curr Opin Cell Biol 47:72-82. CrossRef Medline

Melentijevic I, Toth ML, Arnold ML, Guasp RJ, Harinath G, Nguyen KC, Taub D, Parker JA, Neri C, Gabel CV, Hall DH, Driscoll M (2017) C. elegans neurons jettison protein aggregates and mitochondria under neurotoxic stress. Nature 542:367-371. CrossRef Medline

Menkes JH (1988) Kinky hair disease: twenty five years later. Brain Dev 10:77-79. CrossRef Medline

Menkes JH (1999) Menkes disease and Wilson disease: two sides of the same copper coin: I. Menkes disease. Eur J Paediatr Neurol 3:147-158. CrossRef Medline

Menkes JH, Alter M, Steigleder GK, Weakley DR, Sung JH (1962) A sexlinked recessive disorder with retardation of growth, peculiar hair, and focal cerebral and cerebellar degeneration. Pediatrics 29:764-779. Medline

Mizushima N, Komatsu M (2011) Autophagy: renovation of cells and tissues. Cell 147:728-741. CrossRef Medline

Morgan JR, Comstra HS, Cohen M, Faundez V (2013) Presynaptic membrane retrieval and endosome biology: defining molecularly heterogeneous synaptic vesicles. Cold Spring Harb Perspect Biol 5:a016915. CrossRef Medline

Naj AC, Jun G, Beecham GW, Wang LS, Vardarajan BN, Buros J, Gallins PJ, Buxbaum JD, Jarvik GP, Crane PK, Larson EB, Bird TD, Boeve BF, GraffRadford NR, De Jager PL, Evans D, Schneider JA, Carrasquillo MM, Ertekin-Taner N, Younkin SG, et al. (2011) Common variants at MS4A4/MS4A6E, CD2AP, CD33 and EPHA1 are associated with lateonset Alzheimer's disease. Nat Genet 43:436-441. CrossRef Medline

Naslavsky N, Caplan S (2018) The enigmatic endosome: sorting the ins and outs of endocytic trafficking. J Cell Sci 131:jcs216499. CrossRef Medline

Niederst ED, Reyna SM, Goldstein LS (2015) Axonal amyloid precursor protein and its fragments undergo somatodendritic endocytosis and processing. Mol Biol Cell 26:205-217. CrossRef Medline

Nikoletopoulou V, Tavernarakis N (2018) Regulation and roles of autophagy at synapses. Trends Cell Biol 28:646-661. CrossRef Medline

Nikoletopoulou V, Sidiropoulou K, Kallergi E, Dalezios Y, Tavernarakis N (2017) Modulation of autophagy by BDNF underlies synaptic plasticity. Cell Metab 26:230-242.e5. CrossRef Medline

Nishiyama J, Miura E, Mizushima N, Watanabe M, Yuzaki M (2007) Aberrant membranes and double-membrane structures accumulate in the axons of Atg5-null Purkinje cells before neuronal death. Autophagy 3:591596. CrossRef Medline

Nixon RA (2013) The role of autophagy in neurodegenerative disease. Nat Med 19:983-997. CrossRef Medline

Nixon RA, Wegiel J, Kumar A, Yu WH, Peterhoff C, Cataldo A, Cuervo AM (2005) Extensive involvement of autophagy in Alzheimer disease: an immuno-electron microscopy study. J Neuropathol Exp Neurol 64:113122. CrossRef Medline

Okerlund ND, Schneider K, Leal-Ortiz S, Montenegro-Venegas C, Kim SA,
Garner LC, Waites CL, Gundelfinger ED, Reimer RJ, Garner CC (2017) Bassoon controls presynaptic autophagy through Atg5. Neuron 93:897913.e7. CrossRef Medline

Padamsey Z, McGuinness L, Bardo SJ, Reinhart M, Tong R, Hedegaard A, Hart ML, Emptage NJ (2017) Activity-dependent exocytosis of lysosomes regulates the structural plasticity of dendritic spines. Neuron 93: 132-146. CrossRef Medline

Paik SR, Shin HJ, Lee JH, Chang CS, Kim J (1999) Copper(II)-induced selfoligomerization of alpha-synuclein. Biochem J 340:821-828. CrossRef Medline

Petris MJ, Mercer JF (1999) The Menkes protein (ATP7A; MNK) cycles via the plasma membrane both in basal and elevated extracellular copper using a C-terminal di-leucine endocytic signal. Hum Mol Genet 8:21072115. CrossRef Medline

Phillips-Krawczak CA, Singla A, Starokadomskyy P, Deng Z, Osborne DG, Li H, Dick CJ, Gomez TS, Koenecke M, Zhang JS, Dai H, SifuentesDominguez LF, Geng LN, Kaufmann SH, Hein MY, Wallis M, McGaughran J, Gecz J, Sluis Bv, Billadeau DD, et al. (2015) COMMD1 is linked to the WASH complex and regulates endosomal trafficking of the copper transporter ATP7A. Mol Biol Cell 26:91-103. CrossRef Medline

Pickles S, Vigié P, Youle RJ (2018) Mitophagy and quality control mechanisms in mitochondrial maintenance. Curr Biol 28:R170-R185. CrossRef Medline

Pickrell AM, Youle RJ (2015) The roles of PINK1, parkin, and mitochondrial fidelity in Parkinson's disease. Neuron 85:257-273. CrossRef Medline

Price JC, Guan S, Burlingame A, Prusiner SB, Ghaemmaghami S (2010) Analysis of proteome dynamics in the mouse brain. Proc Natl Acad Sci U S A 107:14508-14513. CrossRef Medline

Progida C, Malerød L, Stuffers S, Brech A, Bucci C, Stenmark H (2007) RILP is required for the proper morphology and function of late endosomes. J Cell Sci 120:3729-3737. CrossRef Medline

Raiborg C, Wenzel EM, Stenmark H (2015a) ER-endosome contact sites: molecular compositions and functions. EMBO J 34:1848-1858. CrossRef Medline

Raiborg C, Wenzel EM, Pedersen NM, Olsvik H, Schink KO, Schultz SW, Vietri M, Nisi V, Bucci C, Brech A, Johansen T, Stenmark H (2015b) Repeated ER-endosome contacts promote endosome translocation and neurite outgrowth. Nature 520:234-238. CrossRef Medline

Rangaraju V, Calloway N, Ryan TA (2014) Activity-driven local ATP synthesis is required for synaptic function. Cell 156:825-835. CrossRef Medline

Rasia RM, Bertoncini CW, Marsh D, Hoyer W, Cherny D, Zweckstetter M, Griesinger C, Jovin TM, Fernández CO (2005) Structural characterization of copper(II) binding to alpha-synuclein: insights into the bioinorganic chemistry of Parkinson's disease. Proc Natl Acad Sci U S A 102: 4294-4299. CrossRef Medline

Rocha N, Kuijl C, van der Kant R, Janssen L, Houben D, Janssen H, Zwart W, Neefjes J (2009) Cholesterol sensor ORP1L contacts the ER protein VAP to control Rab7-RILP-p150 glued and late endosome positioning. J Cell Biol 185:1209-1225. CrossRef Medline

Rogaeva E, Meng Y, Lee JH, Gu Y, Kawarai T, Zou F, Katayama T, Baldwin CT, Cheng R, Hasegawa H, Chen F, Shibata N, Lunetta KL, PardossiPiquard R, Bohm C, Wakutani Y, Cupples LA, Cuenco KT, Green RC, Pinessi L, et al. (2007) The neuronal sortilin-related receptor SORL1 is genetically associated with Alzheimer disease. Nat Genet 39:168-177. CrossRef Medline

Rowland AA, Chitwood PJ, Phillips MJ, Voeltz GK (2014) ER contact sites define the position and timing of endosome fission. Cell 159:1027-1041. CrossRef Medline

Rowland AM, Richmond JE, Olsen JG, Hall DH, Bamber BA (2006) Presynaptic terminals independently regulate synaptic clustering and autophagy of GABAA receptors in Caenorhabditis elegans. J Neurosci 26:1711-1720. CrossRef Medline

Ryder PV, Vistein R, Gokhale A, Seaman MN, Puthenveedu MA, Faundez V (2013) The WASH complex, an endosomal Arp2/3 activator, interacts with the Hermansky-Pudlak syndrome complex BLOC-1 and its cargo phosphatidylinositol-4-kinase type IIalpha. Mol Biol Cell 24:2269-2284. CrossRef Medline

Sannerud R, Declerck I, Peric A, Raemaekers T, Menendez G, Zhou L, Veerle B, Coen K, Munck S, De Strooper B, Schiavo G, Annaert W (2011) ADP ribosylation factor 6 (ARF6) controls amyloid precursor protein (APP) 
processing by mediating the endosomal sorting of BACE1. Proc Natl Acad Sci U S A 108:E559-E568. CrossRef Medline

Schäffner I, Minakaki G, Khan MA, Balta EA, Schlotzer-Schrehardt U, Schwarz TJ, Beckervordersandforth R, Winner B, Webb AE, DePinho RA, Paik J, Wurst W, Klucken J, Lie DC (2018) FoxO function is essential for maintenance of autophagic flux and neuronal morphogenesis in adult neurogenesis. Neuron 99:1188-1203.e6. CrossRef Medline

Schneider A, Rajendran L, Honsho M, Gralle M, Donnert G, Wouters F, Hell SW, Simons M (2008) Flotillin-dependent clustering of the amyloid precursor protein regulates its endocytosis and amyloidogenic processing in neurons. J Neurosci 28:2874-2882. CrossRef Medline

Schneider JL, Cuervo AM (2014) Autophagy and human disease: emerging themes. Curr Opin Genet Dev 26:16-23. CrossRef Medline

Seaman MN (2004) Cargo-selective endosomal sorting for retrieval to the Golgi requires retromer. J Cell Biol 165:111-122. CrossRef Medline

Setty SR, Tenza D, Sviderskaya EV, Bennett DC, Raposo G, Marks MS (2008) Cell-specific ATP7A transport sustains copper-dependent tyrosinase activity in melanosomes. Nature 454:1142-1146. CrossRef Medline

Shehata M, Matsumura H, Okubo-Suzuki R, Ohkawa N, Inokuchi K (2012) Neuronal stimulation induces autophagy in hippocampal neurons that is involved in AMPA receptor degradation after chemical long-term depression. J Neurosci 32:10413-10422. CrossRef Medline

Simons M, Ikonen E, Tienari PJ, Cid-Arregui A, Mönning U, Beyreuther K, Dotti CG (1995) Intracellular routing of human amyloid protein precursor: axonal delivery followed by transport to the dendrites. J Neurosci Res 41:121-128. CrossRef Medline

Small SA, Petsko GA (2015) Retromer in Alzheimer disease, Parkinson disease and other neurological disorders. Nat Rev Neurosci 16:126-132. CrossRef Medline

Soukup SF, Kuenen S, Vanhauwaert R, Manetsberger J, Hernández-Diaz S, Swerts J, Schoovaerts N, Vilain S, Gounko NV, Vints K, Geens A, De Strooper B, Verstreken P (2016) A LRRK2-dependent EndophilinA phosphoswitch is critical for macroautophagy at presynaptic terminals. Neuron 92:829-844. CrossRef Medline

Spiller KJ, Restrepo CR, Khan T, Dominique MA, Fang TC, Canter RG, Roberts CJ, Miller KR, Ransohoff RM, Trojanowski JQ, Lee VM (2018) Microglia-mediated recovery from ALS-relevant motor neuron degeneration in a mouse model of TDP-43 proteinopathy. Nat Neurosci 21:329340. CrossRef Medline

Stavoe AK, Hill SE, Hall DH, Colón-Ramos DA (2016) KIF1A/UNC-104 transports ATG-9 to regulate neurodevelopment and autophagy at synapses. Dev Cell 38:171-185. CrossRef Medline

Steinberg F, Gallon M, Winfield M, Thomas EC, Bell AJ, Heesom KJ, Tavaré JM, Cullen PJ (2013) A global analysis of SNX27-retromer assembly and cargo specificity reveals a function in glucose and metal ion transport. Nat Cell Biol 15:461-471. CrossRef Medline

Sullivan SE, Dillon GM, Sullivan JM, Ho A (2014) Mint proteins are required for synaptic activity-dependent amyloid precursor protein (APP) trafficking and amyloid beta generation. J Biol Chem 289:15374-15383. CrossRef Medline

Sun J, Roy S (2018) The physical approximation of APP and BACE-1: a key event in Alzheimer's disease pathogenesis. Dev Neurobiol 78:340-347. CrossRef Medline

Sun M, Zhang H (2017) Par3 and aPKC regulate BACE1 endosome-toTGN trafficking through PACS1. Neurobiol Aging 60:129-140. CrossRef Medline

Sun M, Asghar SZ, Zhang H (2016) The polarity protein Par3 regulates APP trafficking and processing through the endocytic adaptor protein numb. Neurobiol Dis 93:1-11. CrossRef Medline

Tammineni P, Cai Q (2017) Defective retrograde transport impairs autophagic clearance in Alzheimer disease neurons. Autophagy 13:982-984. CrossRef Medline

Tammineni P, Ye X, Feng T, Aikal D, Cai Q (2017a) Impaired retrograde transport of axonal autophagosomes contributes to autophagic stress in Alzheimer's disease neurons. Elife 6:e21776. CrossRef Medline

Tammineni P, Jeong YY, Feng T, Aikal D, Cai Q (2017b) Impaired axonal retrograde trafficking of the retromer complex augments lysosomal deficits in Alzheimer's disease neurons. Hum Mol Genet 26:4352-4366. CrossRef Medline

Tang FL, Liu W, Hu JX, Erion JR, Ye J, Mei L, Xiong WC (2015) VPS35 deficiency or mutation causes dopaminergic neuronal loss by impairing mitochondrial fusion and function. Cell Rep 12:1631-1643. CrossRef Medline

Tang G, Gudsnuk K, Kuo SH, Cotrina ML, Rosoklija G, Sosunov A, Sonders MS, Kanter E, Castagna C, Yamamoto A, Yue Z, Arancio O, Peterson BS, Champagne F, Dwork AJ, Goldman J, Sulzer D (2014) Loss of mTORdependent macroautophagy causes autistic-like synaptic pruning deficits. Neuron 83:1131-1143. CrossRef Medline

Tanik SA, Schultheiss CE, Volpicelli-Daley LA, Brunden KR, Lee VM (2013) Lewy body-like alpha-synuclein aggregates resist degradation and impair macroautophagy. J Biol Chem 288:15194-15210. CrossRef Medline

Tas RP, Chazeau A, Cloin BM, Lambers ML, Hoogenraad CC, Kapitein LC (2017) Differentiation between oppositely oriented microtubules controls polarized neuronal transport. Neuron 96:1264-1271.e5. CrossRef Medline

Terenzio M, Schiavo G, Fainzilber M (2017) Compartmentalized signaling in neurons: from cell biology to neuroscience. Neuron 96:667-679. CrossRef Medline

Tümer Z (2013) An overview and update of ATP7A mutations leading to Menkes disease and occipital horn syndrome. Hum Mutat 34:417-429. CrossRef Medline

Ubelmann F, Burrinha T, Salavessa L, Gomes R, Ferreira C, Moreno N, Guimas Almeida C (2017) Bin 1 and CD2AP polarise the endocytic generation of beta-amyloid. EMBO Rep 18:102-122. CrossRef Medline

van der Kant R, Fish A, Janssen L, Janssen H, Krom S, Ho N, Brummelkamp T, Carette J, Rocha N, Neefjes J (2013) Late endosomal transport and tethering are coupled processes controlled by RILP and the cholesterol sensor ORP1L. J Cell Sci 126:3462-3474. CrossRef Medline

Vidal M, Cusick ME, Barabási AL (2011) Interactome networks and human disease. Cell 144:986-998. CrossRef Medline

Vulpe C, Levinson B, Whitney S, Packman S, Gitschier J (1993) Isolation of a candidate gene for Menkes disease and evidence that it encodes a copper-transporting ATPase. Nat Genet 3:7-13. CrossRef Medline

Wang CL, Tang FL, Peng Y, Shen CY, Mei L, Xiong WC (2012) VPS35 regulates developing mouse hippocampal neuronal morphogenesis by promoting retrograde trafficking of BACE1. Biol Open 1:1248-1257. CrossRef Medline

Wang S, Bellen HJ (2015) The retromer complex in development and disease. Development 142:2392-2396. CrossRef Medline

Wang T, Martin S, Papadopulos A, Harper CB, Mavlyutov TA, Niranjan D, Glass NR, Cooper-White JJ, Sibarita JB, Choquet D, Davletov B, Meunier FA (2015) Control of autophagosome axonal retrograde flux by presynaptic activity unveiled using botulinum neurotoxin type a. J Neurosci 35:6179-6194. CrossRef Medline

Wang W, Wang X, Fujioka H, Hoppel C, Whone AL, Caldwell MA, Cullen PJ, Liu J, Zhu X (2016) Parkinson's disease-associated mutant VPS35 causes mitochondrial dysfunction by recycling DLP1 complexes. Nat Med 22:54-63. CrossRef Medline

Wang YC, Lauwers E, Verstreken P (2017) Presynaptic protein homeostasis and neuronal function. Curr Opin Genet Dev 44:38-46. CrossRef Medline

Wei W, Nguyen LN, Kessels HW, Hagiwara H, Sisodia S, Malinow R (2010) Amyloid beta from axons and dendrites reduces local spine number and plasticity. Nat Neurosci 13:190-196. CrossRef Medline

Weidberg H, Shvets E, Elazar Z (2011) Biogenesis and cargo selectivity of autophagosomes. Annu Rev Biochem 80:125-156. CrossRef Medline

Wijdeven RH, Janssen H, Nahidiazar L, Janssen L, Jalink K, Berlin I, Neefjes J (2016) Cholesterol and ORP1L-mediated ER contact sites control autophagosome transport and fusion with the endocytic pathway. Nat Commun 7:11808. CrossRef Medline

Wong YC, Holzbaur EL (2014a) The regulation of autophagosome dynamics by huntingtin and HAP1 is disrupted by expression of mutant huntingtin, leading to defective cargo degradation. J Neurosci 34:1293-1305. CrossRef Medline

Wong YC, Holzbaur EL (2014b) Optineurin is an autophagy receptor for damaged mitochondria in parkin-mediated mitophagy that is disrupted by an ALS-linked mutation. Proc Natl Acad Sci U S A 111:E4439-E4448. CrossRef Medline

Xie Y, Zhou B, Lin MY, Wang S, Foust KD, Sheng ZH (2015) Endolysosomal deficits augment mitochondria pathology in spinal motor neurons of asymptomatic fALS mice. Neuron 87:355-370. CrossRef Medline

Yamamoto A, Yue Z (2014) Autophagy and its normal and pathogenic states in the brain. Annu Rev Neurosci 37:55-78. CrossRef Medline 
Yamazaki T, Koo EH, Selkoe DJ (1996) Trafficking of cell-surface amyloid beta-protein precursor: II. Endocytosis, recycling and lysosomal targeting detected by immunolocalization. J Cell Sci 109:999-1008. Medline

Yap CC, Winckler B (2015) Adapting for endocytosis: roles for endocytic sorting adaptors in directing neural development. Front Cell Neurosci 9:119. CrossRef Medline

Yap CC, Digilio L, McMahon LP, Garcia AD, Winckler B (2018) Degradation of dendritic cargos requires Rab7-dependent transport to somatic lysosomes. J Cell Biol 217:3141-3159. CrossRef Medline

Ye M, Lehigh KM, Ginty DD (2018) Multivesicular bodies mediate longrange retrograde NGF-TrkA signaling. Elife 7:e33012. CrossRef Medline

Ye X, Cai Q (2014) Snapin-mediated BACE1 retrograde transport is essential for its degradation in lysosomes and regulation of APP processing in neurons. Cell Rep 6:24-31. CrossRef Medline

Ye X, Sun X, Starovoytov V, Cai Q (2015) Parkin-mediated mitophagy in mutant hAPP neurons and Alzheimer's disease patient brains. Hum Mol Genet 24:2938-2951. CrossRef Medline

Ye X, Feng T, Tammineni P, Chang Q, Jeong YY, Margolis DJ, Cai H, Kusnecov A, Cai Q (2017) Regulation of synaptic amyloid-beta generation through BACE1 retrograde transport in a mouse model of Alzheimer's disease. J Neurosci 37:2639-2655. CrossRef Medline

Yi L, Kaler SG (2015) Direct interactions of adaptor protein complexes 1 and 2 with the copper transporter ATP7A mediate its anterograde and retrograde trafficking. Hum Mol Genet 24:2411-2425. CrossRef Medline

Yu WH, Cuervo AM, Kumar A, Peterhoff CM, Schmidt SD, Lee JH, Mohan PS, Mercken M, Farmery MR, Tjernberg LO, Jiang Y, Duff K, Uchiyama
Y, Näslund J, Mathews PM, Cataldo AM, Nixon RA (2005) Macroautophagy: a novel beta-amyloid peptide-generating pathway activated in Alzheimer's disease. J Cell Biol 171:87-98. CrossRef Medline

Yue Z (2007) Regulation of neuronal autophagy in axon: implication of autophagy in axonal function and dysfunction/degeneration. Autophagy 3:139-141. CrossRef Medline

Zhang H, Huang T, Hong Y, Yang W, Zhang X, Luo H, Xu H, Wang X (2018) The retromer complex and sorting nexins in neurodegenerative diseases. Front Aging Neurosci 10:79. CrossRef Medline

Zischka H, Lichtmannegger J, Schmitt S, Jägemann N, Schulz S, Wartini D, Jennen L, Rust C, Larochette N, Galluzzi L, Chajes V, Bandow N, Gilles VS, DiSpirito AA, Esposito I, Goettlicher M, Summer KH, Kroemer G (2011) Liver mitochondrial membrane crosslinking and destruction in a rat model of Wilson disease. J Clin Invest 121:1508-1518. CrossRef Medline

Zlatic SA, Vrailas-Mortimer A, Gokhale A, Carey LJ, Scott E, Burch R, McCall MM, Rudin-Rush S, Davis JB, Hartwig C, Werner E, Li L, Petris M, Faundez V (2018) Rare disease mechanisms identified by genealogical proteomics of copper homeostasis mutant pedigrees. Cell Syst 6:368380.e6. CrossRef Medline

Zlatic S, Comstra HS, Gokhale A, Petris MJ, Faundez V (2015) Molecular basis of neurodegeneration and neurodevelopmental defects in Menkes disease. Neurobiol Dis 81:154-161. CrossRef Medline

Zou L, Wang Z, Shen L, Bao GB, Wang T, Kang JH, Pei G (2007) Receptor tyrosine kinases positively regulate BACE activity and amyloid-beta production through enhancing BACE internalization. Cell Res 17:389-401. CrossRef Medline 